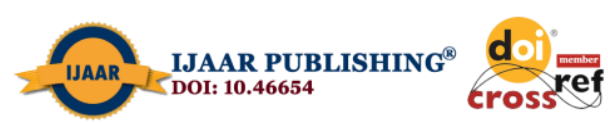

International Journal of Advanced Academic Research (Social and Management Sciences) | ISSN: 2488-9849

Vol. 6, Issue 10 (October, 2020)|www.ijaar.org

Journal DOI: 10.46654/ij.24889849

Article DOI: 10.46654/ij.24889849.s61011

\title{
INFORMAL RELATIONSHIPS ON EMPLOYEE JOB PERFORMANCE: A COMPARATIVE STUDY
}

\author{
UWIMPUHWE Dorothée \\ Master of Business Administration (Management) \\ Tel: +250788573738 \\ uwimpuhwe.doroth@gmail.com
}

\begin{abstract}
This research is aimed at determining and comparing the relationship between informal relationships and employee job performance in the selected technical secondary schools (TSSs) of Muhanga District, Southern Province, in Rwanda. The study was conducted in Ecole Secondaire Bulinga and College Saint Peter of Shyogwe. During this research, both quantitative and qualitative approaches were used in collecting and analyzing data. The population of the study was 43 employees where only 21 out of 26 employees of Ecole Secondaire Bulinga and 17 of College Saint Peter of Shyogwe contributed to the study. The primary data was collected using questionnaires, interviews, and observation; numerical data was analyzed by SPSS software version 22 using descriptive method and analyzed using Pearson correlation coefficient to come up with its interpretation. This study was guided by a null hypothesis which presented no significant influence of informal relationships on employee job performance in the selected TSSs. The statistical evidence depicts that there is a moderate significant relationship between those variables as Pearson Correlation Coefficient is .659 showing a Positive Correlation for ESB while that of College Saint Peter of Shyogwe was .564 which is also positive and significant. Therefore, the null hypothesis was rejected while alternative hypothesis accepted and the researcher confirmed that there exists an influence of informal relationships on employee job performance in the selected TSSs. In the view of the findings derived from the study, some recommendations were made to the selected TSSs like setting informal relationships policies and strategies in order to prevent any negative outcome which can result from relationships that are detrimental to employee job performance and the overall organizational performance.
\end{abstract}

Key Terms: Informal Relationships, Friendship, Acquaintanceship, Platonic Relationship, Professional Relationships, Romantic Relationships, Job Performance, Task Performance, Contextual Performance, Less Counterproductive Behavior. 


\section{INTRODUCTION}

Relationships among people working together are on a basis of mutual understanding, respect, collaboration, and support for a better job performance. However, when spending great time together at workplace, numerous informal relationships are often formed among employees with or without any organizational involvement. This can for many people increase positive sentiments among them as long as their social interactions remain and negative ones cease to exist. These relationships are maintained within organizational settings, strengthening the partnership among employees and once problems occur due to any misunderstanding they break down. Therefore, these informal ties may affect individual thinking, action, and achievement. For instance, they either affect positively or negatively the overall employee job performance.

\section{Problem Statement}

In this study, the researcher seeks to find evidence that workplace informal relationships have an influence on employee job performance in the selected technical secondary schools in Muhanga District. It is therefore important to know whether individuals performing jobs with social jobs characteristics feel these psychological effects, and how this relates to job performance.

For instance, in Rwandan educational institutions, especially in public ones like Ecole Secondaire Bulinga, at the beginning of each academic year, each employee has to sign a performance contract in which informal relationships are taken into consideration as basis of employee job performance measurement. However, it is always reported in educational meetings of public schools with the local government authority that head teachers ignore employees' social interactions which leads to deteriorating their overall performance. Even though informal groups emerge within College Saint Peter of Shyogwe, it seems like within it there is a little understanding of how employees actually interact to get work done. In fact, the school institutional charts fail to reveal the often hidden social networks that truly drive or hinder an individual's performance and most of the time, the head of the school pays little attention to support and assess linkages among employees.

This study will therefore contribute to solve those problems in establishing a basis of understanding by school managers on some aspects of informal relationships, how they influence employee job performance in Ecole Secondaire Bulinga and College Saint Peter of Shyogwe and in particular enabling them to set clear informal relationships and job performance policies which are helpful in the overall employee performance

\section{Objectives of the Study}

The general objective of this study is to determine and compare the relationship between informal relationships and employee job performance of the selected technical secondary schools (TSSs) in Muhanga District.

Specifically, the study seeks to:

1. Determine and compare the relationship between informal relationships and task performance at workplace of Ecole Secondaire Bulinga and College Saint Peter's employees.

2. Determine and compare the relationship between informal relationships and contextual performance at workplace of Ecole Secondaire Bulinga and College Saint Peter's employees. 
3. Determine and compare the relationship between informal relationships and less counterproductive behavior at workplace of Ecole Secondaire Bulinga and College Saint Peter's employees.

\section{Research Hypothesis}

Bailey (1978) explained hypothesis as a proposition in testable form and predicts a particular relationship between two or more variables and that if a researcher thinks that a relationship exists, he/she should first state it as a hypothesis and then test it in the field. Therefore, the research null hypothesis of this study is "There is no significant influence of informal relationships (acquaintanceships, professional relationships, friendships, platonic relationships, romantic relationships) on employee job performance (task performance, contextual performance, less counterproductive behavior) in the selected TSSs".

\section{Justification of the Study}

The researcher's motive of working on this topic is the willingness to know whether or not the workplace informal relationships have an effect on employee job performance. This study is for great importance to the researcher, Ecole Secondaire Bulinga, College Saint Peter of Shyogwe, and further researchers. It will enable the researcher present some realities and get enough knowledge about workplace informal relationships and their influence on employee job performance within organizational settings in order to provide some related advice to the cited TSSs.

At Ecole Secondaire Bulinga and College Saint Peter of Shyogwe level, it will be helpful in reviewing their policies emphasizing on informal relationships available in these institutions and insuring that strategies will inevitably be taken into consideration to enable organizational effectiveness through employee job performance which will also lead to growth and eventually development as far as activities of fostering informal relationships are concerned. Finally, this research paper will be useful to further researchers and scholars being the reference for those having interest in this research field.

\section{Conceptual Framework}

The conceptual framework expresses the reason to conduct this study. Figure 1 shows the approach followed to conduct this study. It is comprised of two variables: dependent variable on the right side which is employee job performance with its sub variables task performance, contextual performance, and less counterproductive behavior while on the left side there is independent variable which is informal relationships with its sub-variables friendships, acquaintanceship, professional relationships, platonic relationships, and romantic relationships. 
Figure 1: Conceptual Framework Model

INDEPENDENT VARIABLE

\begin{tabular}{|l|l|} 
Informal Relationships & Employee Job Performance \\
Friendship & Task Performance \\
Acquaintanceships & Contextual Performance \\
Professional Relationships & $\begin{array}{l}\text { Less-Counter Productive } \\
\text { Behavior }\end{array}$ \\
\hline Romantic Relationships & \\
\hline
\end{tabular}

Source: Researcher's Own Construct, May 2017

\section{REVIEW OF RELATED LITERATURE}

This chapter reviews the related literature on the research topic under study. It is basically related to the views of different authors, academics, scholars, and researchers through their various publications, books, journals, articles, and electronic sources. It includes what the researcher wrote about informal relationships and employee job performance as key concepts, and other terms related to the topic.

\section{Informal Relationships}

Informal relationships refer to engagements or interactions among people outside the established structure of any organization. Unlike formal relationships which have a set of rules and regulations that define relationships between people and tasks, informal relationships do not follow any rules but are formed by people who have certain things in common. They keep on changing depending on work environment and the goals of the group members (Juchem \& Zhou, 2013). Informal context of an organization is therefore about interpersonal relationships that are not based on the formal setup (Wang \& Ahmed 2002). It represents specifically the informal relationships between the employees within an organization (Krackhardt \& Stern, 1988; Krackhardt \& Hanso, 1993).

Other researchers of this research field based on their point of view identified some examples of informal relationships like acquaintanceship, friendship, professional relationships (Morrison \& Cooper-Thomas, 2015), platonic relationships, and romantic relationships (Amir, 2001). These informal relationships are considered as independent variables and are discussed in this paper.

\section{Informal Relationships Related Theories}

There are some theories related to those informal relationships and they are discussed as follows:

Social Exchange Theory: According to Homans (1961), social exchange refers to the exchange of activity, tangible or intangible, and more or less rewarding or costly, between at 
least two persons. Self-interest and interdependence are central properties of social exchange(Lawler \& Thye, 1999).These are the basic forms of interaction when two or more actors have something of value to each other, and they have to decide whether to exchange and in what amounts(Lawler, 2001).

According to the researcher, this theory is highly applicable to the workplace and elsewhere in the society where individuals have duty to help and support each other while performing their tasks or in a case one is in need of social or emotional support. Therefore, the one who has been helped or supported feels indebtedness state and struggles in repaying whoever did so to him/her. It is also obvious that depending on the current situation in which the relationship has to commence, some relationships may be formed without calculating rewards they may provide or costs they may require.

Social Balance Theory: The concept proposed by Heider's Balance Theory discusses the relations among individuals based on sentiment. Balance state over two people (dyad) will occur if the two like each other or dislike each other; meanwhile, if one has a different sentiment relation, thus the relation is imbalance. It is believed that the social (sentiment) relations tend to be in its balance state (Taylor, 1967).

With the researcher's experience, imbalance state among people is based on their personal differences where one may feel discomfort once feel rejected by another intentionally which may disturb his/her moral sentiment creating a tension or a conflict among them leading to disliking one another. Therefore, any factor that influences calmness becomes a source of balance state ascertaining psychological stability in individuals in relationship.

Hersey-Blanchard Theory: The Hersey-Blanchard theory is based on the amount of direction (task behavior) and socio-emotional support (relationship behavior) a leader must provide given the situation and the level of maturity of the followers. Relationship behavior is the extent to which the leader engages in two-way or multi-way communications. This includes listening, facilitating, and supportive behaviors. In relationship behavior the leader engages in two-way communication by providing socio-emotional support (Hersey \& Blanchard, 1977).

With the researcher's point of view, one big destructive tool of employees and organizational performance boundaries is a lack of communication or inadequate one. Therefore, organizations leaders and managers are required to know where, what, when, how, and whom to communicate in order to increase the likelihood of information to be shared. In this situation these leaders/managers must improve their communication skills especially listening capacity as well as they can without ignoring their employees as their main interlocutors. This can be performed though communication training sessions, coaching, and seminars with external experts where possible or applicable.

Adair's Theory: Adair certainly encompassed and endorsed much of the previous thinking on human needs and motivation by Maslow, Herzberg and Fayol. Adair proposed that understanding what motivates individuals to act is fundamental to engaging their interest and focusing their efforts. The will that leads to action is governed by motives, and motives are inner needs or desires that can be conscious, semi-conscious or unconscious. For Adair, a leader/ manager understands the team members as individuals considering their personality, 
skills, strengths, needs, aims and fears; assist and support individuals in their plans, problems, challenges, highs and lows (Adair,1990).

The researcher supports Adair's theory. It is very clear that current organizations operating in a dynamic global environment, in order to become more successful, they can consider to apply this theory. As employees are like corner stones and foundation of organization goals achievement, managers/leaders are required to put into consideration employees' well being, supporting/assisting them socially, morally, emotionally, and financially any time they are in need, emphasis being on their personal differences and treating them equally.

Social Needs Theory: According to Hayes (2009), a person hungers for the affection of others and would want to be placed in a group or family. Relating this to the work place, as outgoing creatures, humans have a need to belong and this can only be satisfied by an ability to interact with one's colleagues and be able to collaborate effectively to achieve organizational goals. According to Abraham Harold Maslow, the love and belonging needs are very important in human life. They are psychological needs of feeling the need for friends, a sweetheart; affectionate relationships in general, even a sense of community; on the contrary, one becomes susceptible to loneliness and social anxieties (Boeree, 2006).

According to the researcher, this theory is highly inspirational. In everyday life, none can ignore that every human being enjoys being part of a social setting. None can choose to be with those who do not care about his/her presence, sadness or happiness neither. It is really satisfying being with people who show you are valuable regardless your downfalls to make you keep your chin up. A friend that is worth having is very important in life, the one you are not obliged to step into his/her feet but who goes beside you, walk, and achieve goals together because he/she cannot let you behind or down. As one among Aristotle quotes says "Without friendship no one can choose to live" and another unknown author said "Without friendship no one can choose to work", therefore, all workplaces might be friendly homes and remedy of loneliness for those desperate employees in trouble.

The informal relationships outlined earlier as independent variables are discussed as follows:

\section{Friendship}

Friendship is defined as close relationship among friends (Huang, 2008). Therefore, people express their friendship through emotion and behavior (Huang, 2008; Spencer, 2012) and a number of modern writers (Pahl, 2000; Doyle \& Smith, 2002; Mao, 2006) present friendships as private, voluntary and happening between autonomous individuals. At workplace, they refer to individuals' friendship with their peers, subordinates, and superiors (Austin, 2009; Lee, 2005; Mao \& Hsieh, 2012).

\section{Acquaintanceship}

Acquaintances are characterized primarily by social interactions and lack the intimacy, sense of uniqueness, degree of affection, and obligations associated with personal friendship (Bridge \& Baxter, 1992). Wright (1988) distinguishes friendship from acquaintance relationship by the additional behaviors that friends engage in with one another, including shared voluntary activities and intimacy such as self-disclosure and emotional support. Pahl (2000) explains that a relationship with an acquaintance is superficial, not depending on confidences or intimacies. He describes acquaintances as being a product of the situation. 
When the particular situation is over, when your mutual friend is not present, the relationship usually lapses. One factor however that changes this fact is the use of social networking sites, specifically Facebook.

\section{Professional Relationships}

Professional Relationships are formed by individuals working together for the same organization. These are said to share a professional relationship and they are called colleagues. Colleagues may or may not like each other (Morrison \& Cooper-Thomas, 2015). The term professional relationship is used here for the purpose of describing all relationships between staff, trained or untrained, and service users, their families or careers. It is important to distinguish between friendliness as a quality in professional contact and personal friendships. Other personal professional qualities like patience, sensitivity, initiative, honesty, courtesy, empathy, trustworthiness and good humor are important in maintaining such relationships (Gert, 2007).

\section{Platonic Relationships}

Platonic Relationships are relationships between two cross-gender individuals without any feelings or sexual desire for each other. Platonic relationships might end in romantic relationship with both the partners developing mutual love and falling for each other (Amir, 2001). Messeman, Canary, and Hause (2000) found that the main motivation for maintaining a platonic friendship is to sustain a safeguard relationship with someone, meaning that the friendship is maintained as a potential alternative in case the current romantic relationship fails. Although Guerrero and Chavez (2005) noted that most relationships are perceived as platonic, meaning there is no sexual involvement between the two members; the lack of social scripts blurs the boundaries and may lead to these individuals acting on their sense of sexual attraction. Ellis (1992) states that people logically consider potential mating partners based on their mate value: the higher they feel they are of value in the environment, the more likely they are to become sexually attracted to them.

\section{Romantic Relationships}

Romantic relationships have a peculiar intensity and the intensity can be marked by expressions of affection including physical ones and, perhaps, the expectation of sexual relations (Brown, Furman, \& Feiring, 1999; Reis \& Shaver, 1988). They are therefore defined as mutually desired relationships involving sexual attraction between individuals (Pierce \& Aguinis, 2001). There are two types of workplace romance, lateral and hierarchical (Karl \& Sutton, 2000; Pierce \& Aguinis, 1997). A lateral romance is a relationship between employees of equal status. A hierarchical romance is one where the two employees are at different organizational levels, as when a manager is romantically involved with his or her subordinate. Hierarchical workplace romances are both more frequent and more problematic than lateral romances, involving power differences between those in the partnership, and are often a source of hostility (Powell, 2001).

Apart from informal relationships as independent variable discussed, the dependent variable of the study to be discussed in this research paper is employee job performance.

\section{Employee Job Performance}

The nature of job performance in an organization depends on the demands of the job, the goals and mission of the organization and beliefs in the organization about which behaviors 
are most valued (Motowidlo \& Schmit, 1999; Murphy \& Shiarella, 1997). Borman and Motowidlo (1993) presented a model of job performance which reflected such behaviors that were comprehensive of job performance specialty, classified as either task or relative performance. In the performance literature, a distinction is made between in role and extrarole performance (Katz \& Kahn, 1978). Extra-role performance is also conceptualized as organizational citizenship behaviors (Smith, Organ, \& Near, 1983). Both task performance, contextual performance, and less counterproductive behavior are behaviors to be considered as the determinants of employee job performance in this research paper.

\section{Task Performance}

Task performance in itself can be described as a multi -dimensional construct. Campbell (1990) proposed a hierarchical model of eight performance factors. Among these eight factors, five referring to task performance are job-specific task proficiency; non-job-specific task proficiency; written and oral communication proficiency; supervision, in case of leadership position; and partly management/administration. Each of these five factors itself consists of sub factors which are differently important for various jobs. For example, the supervision factor includes guiding, directing, and motivating subordinates and providing feedback, maintaining good working relationships, and coordinating subordinates and other resources to get the job done (Borma \& Brush, 1993).

\section{Contextual Performance}

Contextual performance was defined as performance that is not formally required as part of the job but that helps shape the social and psychological context of the organization (Borman \& Motowidlo, 1993). It has been further suggested to have two facets: interpersonal facilitation and job dedication. Interpersonal facilitation includes cooperative, considerate, and helpful acts that assist co-workers' performance. On the other hand, job dedication includes self-disciplined, motivated acts such as working hard, taking initiative, and following rules to support organizational objectives (Van Scotter \& Motowidlo, 1996)

\section{Less Counterproductive Behavior}

Robinson and Bennett (1995) created a four-class typology of counterproductive work behavior divided into dimensions; production deviance, involving behaviors like leaving early, intentionally working slow, or taking long breaks; property deviance, involving sabotage of equipment, theft of property, and taking kickbacks; political deviance, involving showing favoritism, gossiping, or blaming others; and personal aggression, involving harassment, verbal abuse, and endangerment.

\section{Effects of Informal Relationships on Employee Job Performance}

Ross (1997) stated that workplace friendships significantly improve performance at one condition that friends must be strongly committed to group's or organization's objectives goals otherwise managers may be better off keeping them apart. Although some research has indicated that friendships among group members may have a negative effect on their performance because the focus may be on the social interaction rather than on the task (Bramel\& Friend, 1987), other research assumes that improved interpersonal relationships (i.e friendships) lead to improved task performance through a reduction in process loss, a process loss being the extent to which group processes are hindered by misunderstanding, miscommunications, and dislikes resulting in wasted energy. Researchers find positive effect of workplace friendships on organizational outcome and employee performance specifically, on job stress, employee attitude, critical and creative thinking, job involvement employee 
satisfaction and commitment and turnover intentions (Shellenbarger, 2000; Sias et al, 2004, Ellingwood, 2001; Crabtree, 2004, Morrison, 2004).

Furthermore, a review of the literature by Pierce et al. (1996) on the effect of workplace romance on productivity concludes that a substantial proportion of the literature indicates that job productivity can be negatively affected by workplace liaisons, though (Pierce, 1998) later reports that participating in a workplace romance may not be entirely detrimental to an individual's performance at work while Pierce and Aguinis (2003) found romance not to be predictive of levels of job performance.

Negative effects also include co-worker disapproval, cynicism, and hostility (Anderson \&Fisher, 1991), as well as concerns that there will be favoritism and employment benefits given to one party in the relationship by the other (Anderson \& Hunsaker, 1985). Cole (2009) found that no one reported positive effects of workplace romance on the performance of coworkers or work environment. Any impact was invariably negative. Negative outcomes include conflicts of interest, flawed or biased decision-making and other workplace inequities that have a negative impact on both individual and organizational performance as well as the careers of one or both partners (Powell, 1993).

\section{RESEARCH METHODOLOGY}

The research methodology details tools and techniques that were applied to achieve the objectives of this study. This study is a correlation comparative research design where researchers used Pearson correlation coefficient to interpret the data to establish the relationship between informal relationships and employee job performance. The total population of the study was 43 employees where 26 employees of Ecole Secondaire Bulinga and 17 of College Saint Peter of Shyogwe were supposed to contribute to the study. The primary data was collected using questionnaires, interviews, and observation; numerical data were analyzed by SPSS software version 22 using descriptive method and analyzed Pearson correlation coefficient to come up with its interpretation.

The researcher used structured questionnaires to collect data from respondents through closed questions (following Likert four point scales) and open ones. To ensure the validity and reliability of the questionnaire, the research advisor and a statistician were consulted to find out whether or not the questions should enable researchers to achieve research objectives. All data collected from respondents were organized, edited, codified, and analyzed through the Statistical Package of Social Science (SPSS) using tables in a simplified way so as to meet specific requirements of the research and data analysis using Pearson correlation coefficient.

\section{RESULTS AND DISCUSSION}

The results of this study whose purpose was to compare the Pearson Correlation Coefficients(r) between informal relationship and task performance, contextual performance, less counterproductive behavior and employee job performance in the selected technical secondary schools are presented as follows: 
Comparison of Pearson Correlation Coefficients

\begin{tabular}{|c|c|c|c|c|}
\hline TSS & $\begin{array}{l}\text { Pearson } \\
\text { correlation } \\
\text { coefficient } \\
\text { between } \\
\text { Informal } \\
\text { relationships } \\
\text { and Task } \\
\text { Performance }\end{array}$ & $\begin{array}{l}\text { Pearson } \\
\text { correlation } \\
\text { coefficient } \\
\text { between Informal } \\
\text { relationships and } \\
\text { Contextual } \\
\text { Performance }\end{array}$ & $\begin{array}{l}\text { Pearson } \\
\text { correlation } \\
\text { coefficient } \\
\text { between Informal } \\
\text { relationships and } \\
\text { Less } \\
\text { Counterproductiv } \\
\text { e Behavior }\end{array}$ & $\begin{array}{l}\text { Pearson } \\
\text { correlation } \\
\text { coefficient } \\
\text { between } \\
\text { Informal } \\
\text { relationships } \\
\text { and } \\
\text { Employee } \\
\text { Job } \\
\text { Performance }\end{array}$ \\
\hline $\begin{array}{l}\text { College } \\
\text { Saint Peter } \\
\text { of Shyogwe }\end{array}$ & .395 & .629 & .370 & .564 \\
\hline $\begin{array}{l}\text { Ecole } \\
\text { Secondaire } \\
\text { Bulinga }\end{array}$ & .483 & .612 & .512 & .659 \\
\hline
\end{tabular}

Source: Primary Data, June 2017

Based on the Pearson correlation coefficients in the table above, it is seen that for both schools, there exist weak correlations indicating that informal relationships influence less task performance even though a little influence is more in Ecole Secondaire Bulinga ( $\mathrm{r}=$ .483) than in College Saint Peter of Shyogwe ( $r=.395)$ as shown by Pearson correlations of .483 greater than .395 . For Pearson correlation coefficients between informal relationships and contextual performance, both schools have almost the same, College Saint Peter of Shyogwe having a correlation of .629 which is slightly greater than that of Ecole Secondaire Bulinga whose coefficient is .612. This indicates that in those institutions, informal relationships have a certain influence on their employees' contextual performance but more in College Saint Peter of Shyogwe.

Referring to the Pearson correlations coefficients in the table above, informal relationships influence more less counterproductive behavior in Ecole Secondaire Bulinga with a coefficient equal to .512 than in College Saint Peter of Shyogwe whose coefficient is.370. And finally, the table above shows that based on the Pearson correlation coefficients, in general, there exist a relationship between informal relationships and employee job performance in both schools. This is indicated by a coefficient of .659 for Ecole Secondaire Bulinga and that of .564 for College Saint Peter of Shyogwe. And that relationship is higher in Ecole Secondaire Bulinga than in College Saint Peter of Shyogwe.

\section{Hypothesis Testing}

The hypothesis of the study to be tested is:

$\mathrm{H}_{\mathrm{O}}$ : There is no significant influence of informal relationships 
(acquaintanceships, professional relationships, friendships, platonic relationships, romantic relationships) on employee job performance (task performance, contextual performance, less counterproductive behavior) in the selected TSSs.

$\mathrm{H}_{\mathrm{a}}$ : There is a significant influence of informal relationships (acquaintanceships, professional relationships, friendships, platonic relationships, romantic relationships) on employee job performance (task performance, contextual performance, less counterproductive behavior) in the selected TSSs.

However, the statistical evidence depicts that there is a moderate significance in relationship between those variables as Pearson Correlation Coefficient is .659 showing a Positive Correlation for ESB while that of College Saint Peter of Shyogwe was .564 which is also positive, moderate, and significant. The null hypothesis is rejected as p-value equals to .001 is less than alpha equal to .01(2- tailed) for ESB and for College Saint Peter of Shyogwe, p-value is .018 less than alpha equal to .05 (2-tailed), so the alternative hypothesis is accepted. Therefore, the researcher can confirm that there is a significant influence of informal relationships (acquaintanceships, professional relationships, friendships, platonic relationships, romantic relationships) on employee job performance (task performance, contextual performance, less counterproductive behavior) in the selected TSSs.

\section{Conclusion}

The main objective of this study is to determine and compare the relationship between informal relationships and employee job performance of the selected technical secondary schools (TSSs) in Muhanga District which are Ecole Secondaire Bulinga and College Saint Peter of Shyogwe. After analyzing the data collected in these TSSs and referring to specific objectives of the study, the research findings revealed that at College Saint Peter of Shyogwe, there exists a weak relationship between informal relationships and task performance, a moderate relationship between informal relationships and contextual performance, and a weak relationship between informal relationships and less counterproductive behavior while at ESB, there exists a weak relationship between informal relationships and task performance, a moderate relationship between informal relationships and contextual performance, and a moderate relationship between informal relationships and less counterproductive behavior.

After the verification of the null hypothesis, the researcher confirmed that there is a significant influence of informal relationships on employee job performance of the selected technical secondary schools in Muhanga District. Hence, the null hypothesis saying that there is no significant influence of informal relationships on employee job in the selected TSSs is rejected while the alternative hypothesis saying that there is a significant influence of informal relationships on employee job performance is confirmed.

\section{Recommendations}

After analysis of the results, the following recommendations are presented:

Ecole Secondaire Bulinga and College Saint Peter of Shyogwe are recommended to conduct regular trainings for their employees about informal relationships 
and their importance so that they can benefit from them and perform their tasks cohesively and friendly in a sustainable manner. External experts in terms of getting to understand informal relationships can come in handy.

Those TSSs are also recommended to undertake research on how informal relationships can be fostered so that their employees may enjoy a flexible and pleasant workplace.

The school managers of both TSSs are especially recommended to ensure that employees' emotional and social support are well considered in order to maintain good atmosphere, image and unity among employees and students; strengthening good mood among them.

The School managers of those TSSs also are recommended to set informal relationships policies and strategies in order to prevent any negative outcome which can result from those relationships that are detrimental to employee job performance and the overall organizational performance. 


\section{REFERENCES}

Adair, J. (1990). Understanding motivation. Guildford: Talbot Adair Press.

Amir, L.(2001). Plato's theory of Love: Rationality as Passion. Retrieved on 22.11.2016 http://www.practical-philosophy.org.uk.

Anderson, C.J. \& Fisher, C. (1991). Male-female relationships in the workplace: Perceived motivations in office romance. Sex Roles, 25:163-180.

Anderson, C.I. \& Hunsaker, P.L. (1985). Why there's romancing at the office and why it's everybody's problem. Personnel, 62: 57-63.

Austin, C. (2009). An investigation of workplace friendships and how it influences career advancement and job satisfaction: A qualitative case study. Unpublished $\mathrm{PhD}$ 's thesis.Capella University, United States.

Bailey, K. D. (1978). Methods of social research (3rd ed.). New York: The Free Press

Boeree, C.G. (2006).Personality Theories. Retrieved on 24.11.2016 Fromhttp://www.ship.edu/\%7Ecgboeree/perscontents.html

Borman, W. C., \& Motowidlo, S. J. (1993), Expanding the Criterion Domain to Include Elements of Contextual Performance. In N. Schmitt \& W. C. Borman (Eds.), Personnel Selection in Organizations (Pp. 71-98). San Francisco: Jossey-Bass.

Bridge, K., \& Baxter, L. A. (1992). Blended relationships: Friends as work associates. Western Journal of Communication,56: 200-225.

Brown, B. B., Feiring, C., \& Furman, W. (1999).Missing the love boat: Why researchers have shied away from adolescent romance. In W. Furman, B. B. Brown, \& C. Feiring (Eds.),The development of romantic relationships in adolescence. New York: Cambridge University Press.

Campbell, J. P. (1990). Modeling the Performance Prediction Problem in Industrial and Organizational Psychology. 1: 687-732. In M. D. Dunnette and L. M. Hough (eds), Handbook of Industrial and Organizational Psychology. PaloAlto: Consulting Psychologists Press.

Cole, N. (2009). Workplace romance: A justice analysis. Journal of Business Psychology 24: 363-372.

Doyle, M. E., \& Smith, M. K. (2002). Friendship: theory and experience. The encyclopaedia of informal education, Retrieved first 31st July, 2007 from http://www.infed.org./biblio/friendship.htm.

Ellingwood, S. (2001). The collective advantage: Contrary to popular belief, workplace friendships boost profit.Gallup Management Journal, 1(3): 1-2. 
Ellis, B. (1992). The evolution of sexual attraction: evaluative mechanisms in women.Retrieved

Fromhttp://books.google.com/books?hl=en\&lr=\&id=SxX4gRzOS6oC\&oi=fnd\&pg=P A267\&ots=Bg1u9C2OyK\&sig=PVmiaWooTOdy

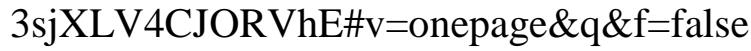

Gert, J. ( 2007). Handouts for Creating and Maintaining Professional Relationships \&Boundaries between Staff and Service Users.

Guerrero, L., \& Chavez, A. (2005). Relational maintenance in cross-sex friendships characterized by different types on romantic intent: an exploratory study. Western Journal ofCommunication. 69(4), 339-358. Retrieved from http://onlineacademics.org/CA104/private/OppositeSexFriends.pdf

Hayes, E. (2009). Managerial Challenges from the Line. : U.K: Pearson.

Hersey, P. and K.H. Blanchard (1977).Management of Organizational Behaviour. Englewood Cliffs NJ:Prentice Hall.

Homans, G. (1961:12-13).Social Behavior: Its Elementary Forms. New York: Harcourt Brace Jovanovich.

Huang, Y. (2008). Conceptualizations of friendship between Chinese international students and U.S. nationals.Unpublished master's thesis. Texas Tech University, United States.

Juchem, B.\&Zhou,Q.(2013). The Increasing Importance of Informal Relationships in Organizations.An Analysis of the Lurking Lions.Leadership and Management in International Context.

Karl, K.A. \& Sutton, C.L. (2000).An examination of the perceived fairness of romance policies.Journal of Business and Psychology, 14: 429-442.

Lawler, E. J. (2001). An Affect Theory of Social Exchange.American Journal of Sociology, 107 (2): 321-352

Lawler, E. J.\&Thye, S. R. (1999). Bringing Emotions into Social Exchange Theory.Annual Review of Sociology.25: 217-244.

Lee, H. E. (2005). Exploration of the relationship between friendship at work and job satisfaction: An application of balance theory. Unpublished master's thesis. Michigan State University, United States.

Mao, H. \& Hsieh, A. (2012).Organizational level and friendship expectation at work.Asian Business \& Management, 11(41): 485-506.

Mao, H.Y. (2006). The relationship between organizational level and workplaceFriendship.The International Journal of Human Resource Management, 17(10): 1819-1833.

Messman, S., Canary, D., Hause, K. (2000).Motives to remain platonic, equity and the use of maintenance strategies in opposite-sex friendships. Journal of Social and Personal Relationships, 17(1): 67-94. 
Morrison, R. (2004). Informal Relationships in the Workplace: Associations with Job Satisfaction, Organizational Commitment and Turnover Intentions. New Zealand Journal of Psychology, 33(3): 114-128.

Morrison, R. L. \& Cooper-Thomas, H. D. (2015) Friendship Among Coworkers. In M. Hojjat\& A. Moyer (Eds.).The Psychology of Friendship. New York: Oxford University Press.

Pahl, R. (2000). On friendship. Cambridge: Polity.

Pierce, C.A. (1998). Factors associated with participating in a romantic relationship in a work environment. Journal of Applied Social Psychology 28: 1712-1730.

Pierce, C.A.\&Aguinis, H. (2003). Romantic relationships in organizations: A test of a model of formation and impact factors. Management Research ,1: 161-169.

Pierce, C.A.\&Aguinis, H. (2001). A framework for investigating the link between workplace romance and sexual harassment.Group and Organization Management, 26: 206- 229.

Pierce, C. A., \&Aguinis, H. (1997). Bridging the gap between romantic relationships and sexual harassrnent in organizations.Journal of Organizational Behavior, (18): 197200.

Pierce, C.A., Byrne, D.\&Aguinis, H. (1996). Attraction in organizations: A model of workplace romance. Journal of Organizational Behavior, 17: 5-32.

Powell, G.N. (2001). Workplace romances between senior-level executives and lower-level employees: An issue of work disruption and gender. Human Relations, 54: 15191544.

Powell, G.N. (1993). Women and Men in Management 2nd edn. Newbury Park, CA: Sage.

Reis, H. T., \& Shaver, P. (1988).Intimacy as an interpersonal process.In S. W. Duck (Ed.).Handbook of personal relationships. New York: Wiley.

Robinson, S. L.; Bennett, R. J. (1995). A typology of deviant workplace behaviors: A multidimensional scaling study. Academy of Management Journal. 38 (2): 555-572.

Ross, J. A. (1997). Does friendship improve job satisfaction? Harvard Business Review, 75(2): 8-9.

Shellenbarger, S. (2000). An overlooked toll of job upheavals: Valuable friendships. Wall Street Journal (Eastern Edition), January 12th, New York, B1.

Sias, P. M., Heath, R. G., Perry, T., Silva, D., \& Fix, B. (2004).Narratives of workplace friendship deterioration.Journal of Social and Personal Relationships, 21: 321-340.

Spencer, S. V. C. (2012). The functions of verbal and nonverbal emotional disclosures to friends during early adolescence: A focus on closeness, friendship satisfaction, and 
internalizing symptoms. Unpublished PhD's thesis. The University at Buffalo, the State University of New York, United States.

Taylor, H.F. (1967). Balance and Change in The Two Person Group. Sociometry, 30(3): 262279.

Van Scotter, J. R. \&Motowidlo, S. J. (1996) Interpersonal facilitation and job dedication as separate facets of contextual performance. Journal of Applied Psychology, 81(5): 525531.

Wang, C.L. \& Ahmed, P.K. (2002:1-13).The informal structure: Hidden energies within an organization. Management Research Centre. Wolverhampton Business School Working Paper Series .University of Wolverhampton, Shropshire.

Wright, P. H. (1988). Interpreting research on gender differences in friendship: A case for moderation and a plea for caution. Journal of Social and Personal Relationships, 5: 367-373. 